\title{
Drought Irrigation Strategies for Alfalfa
}

BLAINE HANSON, University of California Cooperative Extension Irrigation and Drainage Specialist (Emeritus), UC Davis; STEVE ORLOFF, UCCE Farm Advisor, Siskiyou County; DAN PUTNAM, UCCE Specialist, UC Davis.

Alfalfa is California's largest user of agricultural water, due in part to the amount grown - in a typical year about 1 million acres - and to its long growing season. Seasonal irrigation water applications for alfalfa generally range from 4 to 5.5 million acre-feet. Flood irrigation is common in California alfalfa, although some areas such as northern California's intermountain region favor sprinkle irrigation.

Evapotranspiration (ET) is the standard term for quantifying crop water use and is measured in inches of water over the planted area. ET accounts for water that enters the atmosphere through plant leaves (transpiration) as well as water that goes directly from the soil into the air (evaporation). Alfalfa ET values start out low at the beginnning of the crop season, increase to maximum values in the summer, and then decrease again over the remainder of the crop season (Figure 1). Regardless of the time of year, ET follows a cyclical pattern between cuttings: low ET values occur just after cutting, followed by a rapid increase, reaching maximum values just before the next cutting (Figure 1). Recent studies in commercial alfalfa fields throughout California found seasonal ET values for fully irrigated alfalfa that range from 36 to 41 inches of water in the intermountain region, 50 to 60 inches in the Central Valley, and 56 to 65 inches in Imperial Valley, depending on the year. 


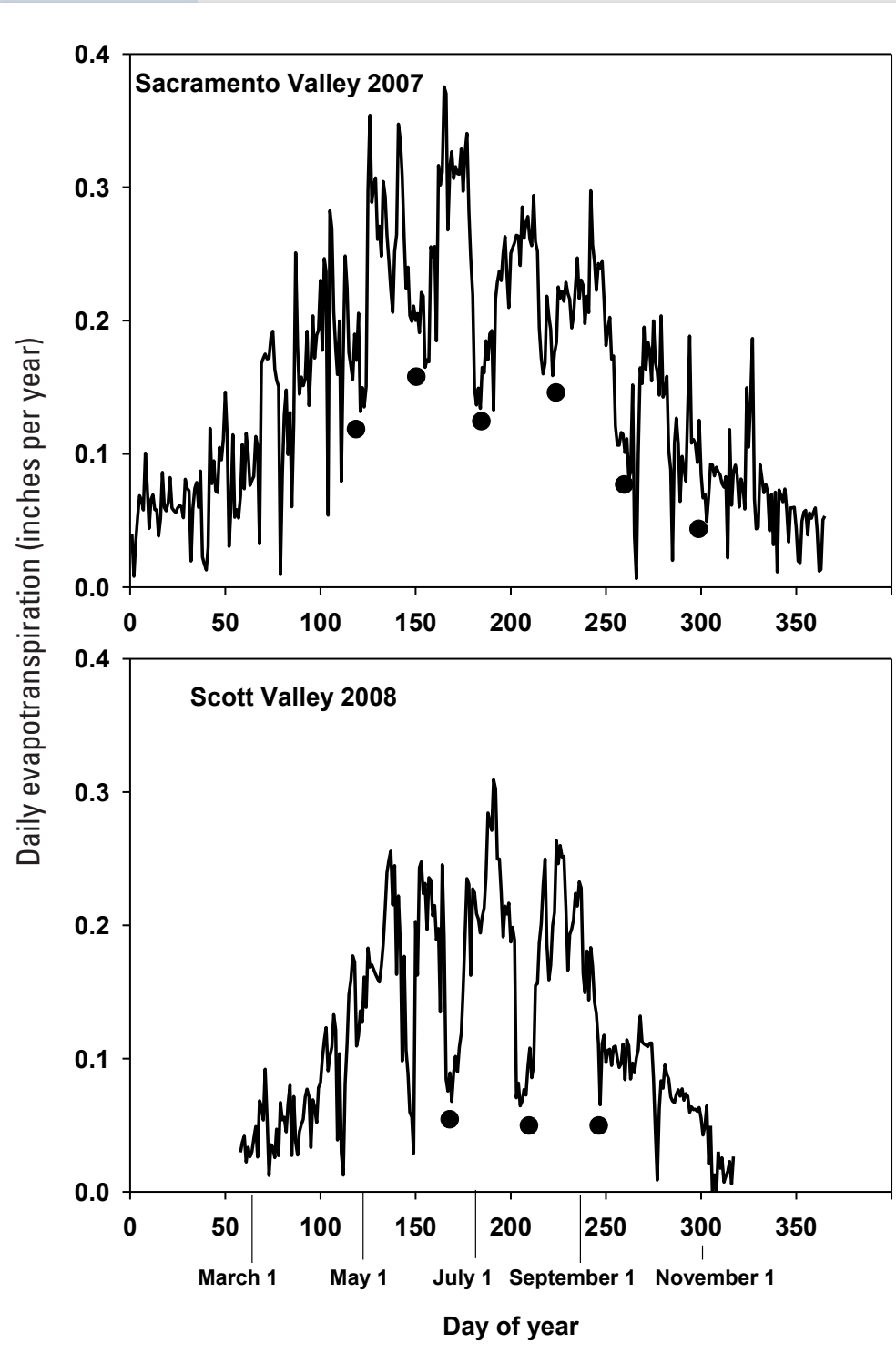

Figure 1. Evapotranspiration of alfalfa for the Sacramento Valley (2007) and Scott Valley (2008). The black dots show the cutting dates.

Numerous studies have shown alfalfa yields to be directly related to ET. Maximum yields occur under maximum ET conditions, which depend on climatic factors such as solar radiation, air temperature, humidity, and wind speed. Both ET and yield can suffer as a result of insufficient soil moisture caused by inadequate irrigation.

California experiences frequent periods of drought as a result of limited rainfall and snow in water storage areas in the northern part of the state, and drought conditions generally dictate reductions in water deliveries to agriculture. In a recent drought, growers in some areas in the southern San Joaquin Valley received only about 10 percent of their normal supply of irrigation water. During drought periods, alfalfa growers may need to implement steps to help minimize the effect of reduced water supplies on their yields. The bottom line, though, is that drought conditions mean lower alfalfa yields. The key to making the best of the situation is to identify strategies that will maximize the profitability of an alfalfa operation during periods of restricted water supply.

\section{Strategies for Coping with Drought}

These are the basic strategies for coping with drought conditions on an alfalfa operation:

- Strategy 1: Reduce the irrigated acreage.

- Strategy 2: Start early in the crop season with full irrigation and continue with full irrigation until the water supply is used up. No irrigations will occur for the rest of the crop season.

- Strategy 3: Practice deficit irrigation over the entire crop season by applying smaller amounts of water than the crop would require if you were trying for maximum yields between cuttings.

\section{Strategy 1 (reduced acreage)}

One drought strategy is to reduce the number of irrigated acres to match the available water supply. The reduced acreage is fully irrigated to obtain maximum ET and maximum yield per acre, following normal irrigation practices. The remaining acreage is not irrigated and so has no yield, but the first-cutting yield for the entire acreage may still be good if sufficient moisture remains in the soil from winter and spring rainfall 
and snowmelt. One concern with this strategy is that the grower needs to make the reduced water supply last the entire crop season. When you consider that there is a potential for further water supply reductions later in the year, you can see that the grower's ability to implement this strategy may be trumped by any additional cuts toward the end of the season.

\section{Strategy 2 (full irrigation followed by no irrigation)}

A second drought strategy is to start irrigations early in the crop season and fully irrigate the entire acreage until the water supply is used up. After that, there can be no more irrigations for the remainder of the crop season. The number of cuttings a grower can get using this method depends on how much water is allocated. The acreage will have maximum ET and maximum yield per acre during the fully irrigated period, but little or no ET or yield during no-irrigation period that follows. This strategy maintains high yields for early harvests and foregoes any expectation of yields later in the season, when smaller yields are the norm in any case. One advantage of this strategy is that the grower uses the entire water allocation earlier in the crop season, before any additional reductions can be implemented.

\section{Strategy 3 (deficit irrigation)}

A third strategy is deficit irrigation of the field throughout the crop season, either by means of applying less water per irrigation, reducing the number of irrigations per cutting, or implementing some combination thereof. This strategy reduces ET as well as yields between harvests and is not recommended if the grower only has access to very small amounts of water, since the yields that are possible from such small water applications may not be economical to harvest.

\section{Which Strategy Is Best?}

The best strategy is the one that provides the largest returns to land and management in your particular situation, and that depends on two factors: how much revenue the crop can generate under reduced yields and how costly it is to implement the particular strategy. All of the major variable production costs are associated with either irrigation or harvest. Variable production costs per acre per harvest are the same for strategy 1 (reduced acreage) as for a fully irrigated field, but because strategy 1 irrigates only part of the field, the field-wide production costs are lower. For strategy 2 ( full irrigation followed by no irrigation), variable production costs per acre per harvest are the same as for a fully irrigated field during the fully irrigated period, but the grower incurs no variable costs during the no-irrigation period. Irrigation and harvests costs for strategy 3 (deficit irrigation) should be lower than those for a fully irrigated field, but we have no reference information we can cite on the actual costs of production for a deficit-irrigated field. We should note, however, that along with these variable costs there are fixed costs that do not change with particular strategies. Fertilizer and pest control costs may be the same for all three strategies since these costs generally occur early in the crop season, before irrigation becomes necessary.

We evaluated the returns to land and management for the first two strategies on the basis of data on the cumulative yield and cumulative ET of fully irrigated alfalfa in the studied commercial fields mentioned earlier in this publication and on other alfalfa production cost data (http://alfalfa.ucdavis.edu/+producing/ index.aspx?/cat=Economics and Marketing). We used crop prices of $\$ 100$ and $\$ 200$ per ton. The production costs that we used to calculate returns to land and management include variable production costs as well as cash overhead costs (taxes, insurance, etc.). 
In general, we found small differences in the returns to land and management under strategies 1 (reduced acreage) and 2 (full irrigation followed by no irrigation). Differences in returns were greatest for small ET values, and the differences decreased as the ET value increased. In some cases, strategy 1 was more profitable than strategy 2 ; in other cases, the opposite was true. When we assumed a crop price of $\$ 100$ per ton, returns remained negative until the ET reached 69 to 79
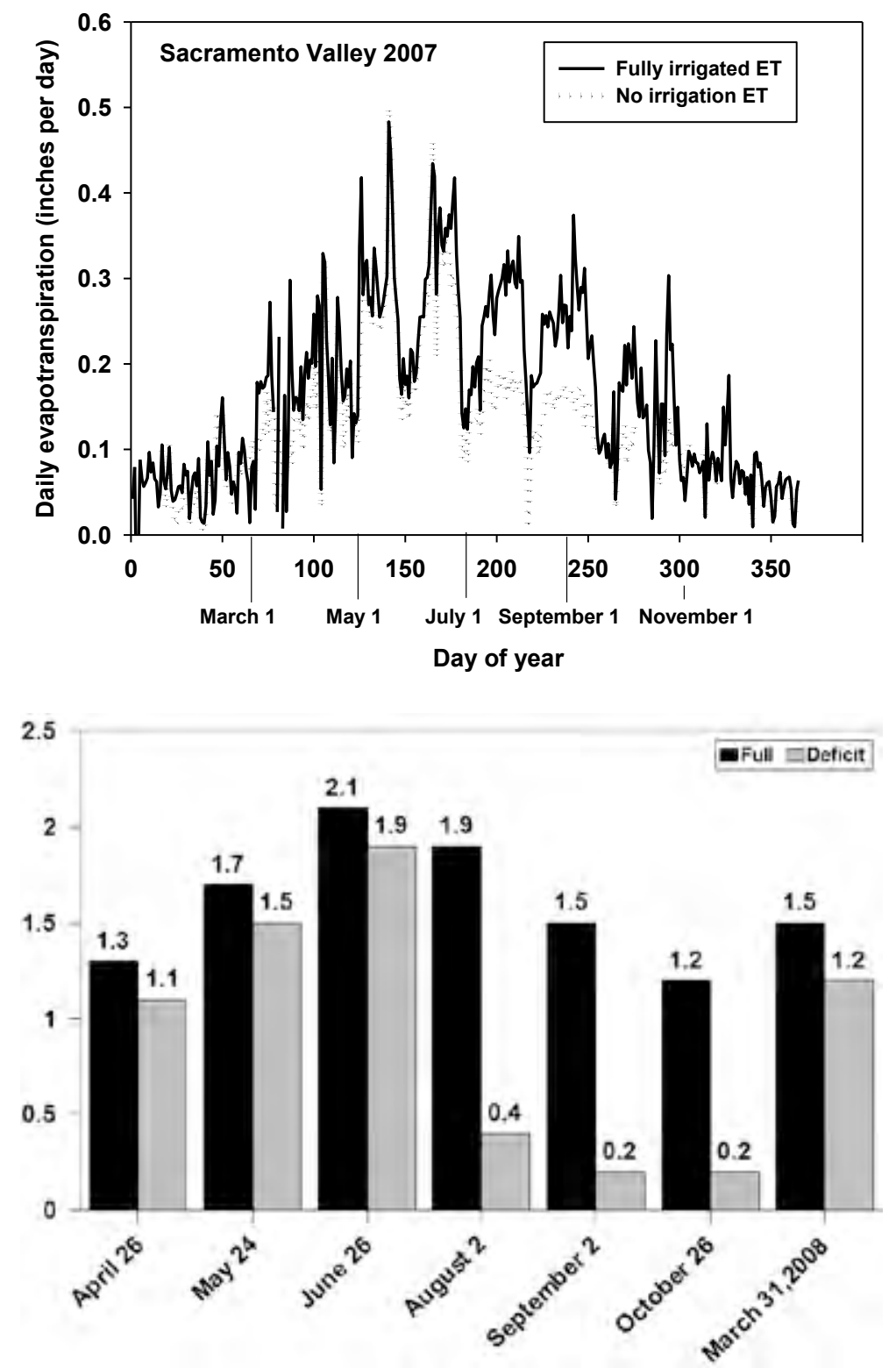

Figure 2. Effect of Strategy 2 (full irrigation followed by no irrigation) on evapotranspiration and yield for the Sacramento Valley 2007 commercial field. Full irrigations occurred for the first part of the crop season; no irrigations occurred after mid-June. percent of a fully irrigated field's value, with the exception of the Sacramento Valley results for 2008, when smaller yields per unit of ET caused negative returns regardless of the ET value. At $\$ 200$ per ton, returns were generally positive for ET values of at least 31 to 49 percent of the fully irrigated ET, depending on the location. We found little difference in the minimum ET required for profitable production using the different strategies at a given crop price.

As stated earlier, alfalfa yield has a linear relationship to ET for deficit-irrigation conditions, but the relationship is site-specific. Thus, for strategy 3 (deficit irrigation), a water supply that provides only 50 percent of the maximum ET will decrease their field's yield by 50 percent, but it is not clear what effect this yield reduction may have on variable costs since the entire field must still be irrigated and harvested. One point to consider is that when particularly small amounts of water are applied, the low yield per acre per harvest under strategy 3 may make the crop uneconomical to harvest. A yield of 0.5 tons per acre is generally considered the threshold value for determining whether it is economical to harvest, but in practice this value can vary depending on crop price.

Based on these results, strategy 2 ( full irrigation followed by no irrigation) is recommended for alfalfa irrigation when water supplies are limited. The effect of this strategy on crop ET and yield for a 2007 Sacramento Valley field is illustrated in Figure 2. The irrigation water was cut off in June after about 50 percent of the seasonal ET had occurred. No irrigations were made after the end of June (180th day of the year). The no-irrigation period reduced both ET and yield, but yields appeared to recover the following year, based on the yield from the first harvest of 2008. 


\section{Stretching a Limited Water Supply}

Efficient irrigation water management is a necessity during the fully irrigated periods of strategies 1 and 2 if you want to stretch limited water supplies during drought conditions. The two main losses that affect irrigation efficiency are deep percolation below the root zone and surface runoff from the field. Efficient irrigation involves determining when to irrigate and then applying the right amount of water.

\section{When to irrigate}

It is difficult to say when the right time is for irrigating alfalfa. A common approach to irrigation scheduling for most crops is to calculate an allowable soil moisture depletion, which depends on the soil type and the crop, and then irrigate when the cumulative ET since the previous irrigation approaches that allowable depletion. This approach does not work for alfalfa because with alfalfa you also have to account for the cutting schedule. No irrigations can occur during the cutting and drying periods. The harvested bales must be removed from the field before the next irrigation can occur, and the last irrigation before a new cutting must be made far enough in advance of the cutting date to allow the soil to get dry enough for harvest operations. This drying period may last 7 to 10 days, depending on irrigation method and soil type. This typically limits alfalfa growers to one, two, or three irrigations between cuttings, although a center-pivot sprinkle irrigation system may allow more than that. The soil moisture depletion before irrigation is likely to exceed the allowable depletion if you apply only one irrigation between cuttings, whereas the depletion is likely to be less than the allowable depletion if you apply multiple irrigations between cuttings. This applies equally to flood-irrigated and sprinkle-irrigated alfalfa.

Soil moisture sensors can determine whether the irrigation frequency and amount are sufficient to meet crop needs between cuttings during periods of full irrigation. Watermark sensors (Watermark is a brand of electrical resistance block) are commonly used in agriculture because they are inexpensive and are easy to install, read, and maintain. These sensors measure soil moisture tension, which increases as the soil's moisture content decreases. The drier the soil, the higher its moisture tension.

Figure 3 shows readings from Watermark sensors that were used to evaluate the adequacy of alfalfa irrigations for one and two flood irrigations between cuttings. For the field with one irrigation between cuttings, soil moisture tension was excessive just before irrigation, with values reaching up to 200 centibars (very dry soil) (Figure 3A), the upper limit of the instrument that was used to read the sensors. Maximum soil moisture tension before irrigation was less than 75 centibars (considered adequate) for the field with two irrigations between harvests (Figure 3B). 

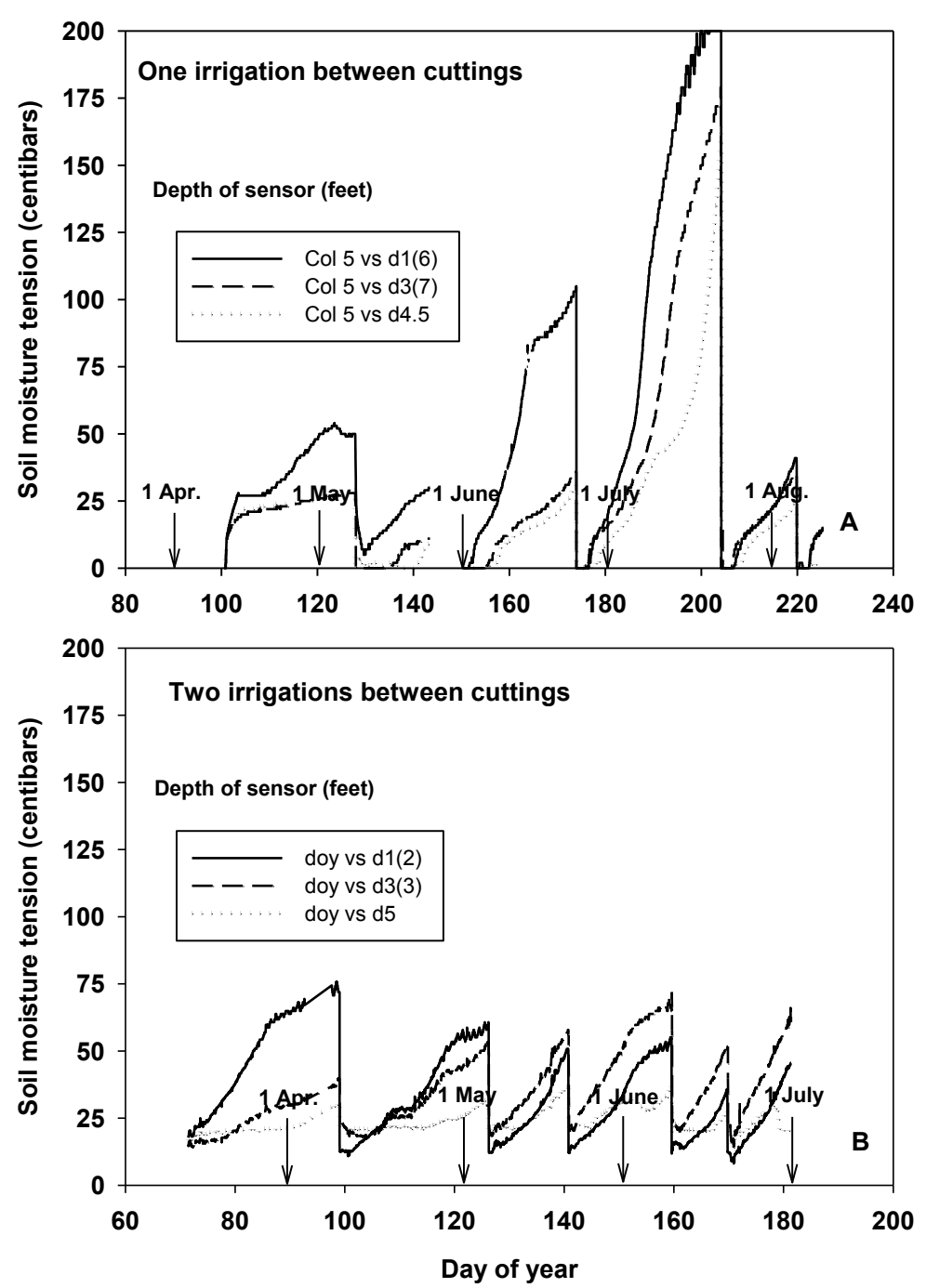

Figure 3. Soil moisture tension measured with Watermark sensors at depths of 1,3 , and 5 feet for (A) one irrigation between cuttings and (B) two irrigations between cuttings. Cuttings occurred about every 30 days.

\section{How much water to apply}

The amount of irrigation water to apply can be calculated from the following equation:

$$
\mathrm{ET}=\mathrm{K}_{\mathrm{c}} \times \mathrm{ET}_{\mathrm{o}}
$$

where ET is the cumulative evapotranspiration in inches for alfalfa since the last irrigation, $K_{c}$ is a crop coefficient for alfalfa, and $\mathrm{ET}_{0}$ is the cumulative reference crop evapotranspiration, in inches, since the last irrigation. Crop coefficients are low (0.3 to 0.5) just after a cutting and are highest (values greater than 1.0) just before the next cutting. However, growers generally use a crop coefficient that is averaged over the crop season in order to simplify calculations (Table 1). Reference evapostranspiration $\left(\mathrm{ET}_{\mathrm{o}}\right)$ is the evapotranspiration of a well-watered grass. Values for $\mathrm{ET}_{\mathrm{o}}$ for many areas of the state are listed at the California Irrigation Management Information System (CIMIS) website (www.cimis.water. ca.gov/cimis). Long-term average or historical values for $\mathrm{ET}_{\mathrm{o}}$ are also available for use (Table 2).

Table 1. Average seasonal crop coefficients $\left(K_{c}\right)$ for various locations in California (values were determined from the ET data collected in the commercial fields mentioned in the text)

\begin{tabular}{cc}
\hline $\begin{array}{c}\text { Location } \\
\text { (from south to north) }\end{array}$ & Crop coefficient $\left(\mathbf{K}_{\mathbf{c}}\right)$ \\
\hline Imperial Valley & 0.91 \\
\hline San Joaquin Valley & 0.99 \\
\hline Sacramento Valley & 0.94 \\
\hline Scott Valley & 0.94 \\
Tulelake & 0.98 \\
\hline
\end{tabular}


Table 2. Historical values of reference crop evapotranspiration $\left(E_{\mathrm{o}}\right)$ in inches per day for various locations in California

\begin{tabular}{|c|c|c|c|c|c|c|c|c|}
\hline Date & Shafter & Five Points & Parlier & Davis & Nicolaus & Durham & McArthur & Brawley \\
\hline & --- & ---- & --- & - inch & per day - - & --- & --- & -- \\
\hline $\begin{array}{c}\text { January } \\
1-15 \\
16-31\end{array}$ & $\begin{array}{l}0.03 \\
0.05\end{array}$ & $\begin{array}{l}0.04 \\
0.05\end{array}$ & $\begin{array}{l}0.03 \\
0.04\end{array}$ & $\begin{array}{l}0.03 \\
0.05\end{array}$ & $\begin{array}{l}0.03 \\
0.04\end{array}$ & $\begin{array}{l}0.03 \\
0.05\end{array}$ & $\begin{array}{l}0.02 \\
0.03\end{array}$ & $\begin{array}{l}0.07 \\
0.09\end{array}$ \\
\hline $\begin{array}{c}\text { March } \\
1-15 \\
16-31\end{array}$ & $\begin{array}{l}0.11 \\
0.14\end{array}$ & $\begin{array}{l}0.11 \\
0.15\end{array}$ & $\begin{array}{l}0.10 \\
0.13\end{array}$ & $\begin{array}{l}0.09 \\
0.14\end{array}$ & $\begin{array}{l}0.09 \\
0.12\end{array}$ & $\begin{array}{l}0.09 \\
0.12\end{array}$ & $\begin{array}{l}0.08 \\
0.11\end{array}$ & $\begin{array}{l}0.16 \\
0.19\end{array}$ \\
\hline $\begin{array}{c}\text { June } \\
1-15 \\
16-30\end{array}$ & $\begin{array}{l}0.27 \\
0.28\end{array}$ & $\begin{array}{l}0.29 \\
0.30\end{array}$ & $\begin{array}{l}0.26 \\
0.27\end{array}$ & $\begin{array}{l}0.28 \\
0.29\end{array}$ & $\begin{array}{l}0.24 \\
0.26\end{array}$ & $\begin{array}{l}0.25 \\
0.26\end{array}$ & $\begin{array}{l}0.22 \\
0.25\end{array}$ & $\begin{array}{l}0.31 \\
0.32\end{array}$ \\
\hline $\begin{array}{c}\text { July } \\
1-15 \\
16-31\end{array}$ & $\begin{array}{l}0.28 \\
0.26\end{array}$ & $\begin{array}{l}0.30 \\
0.28\end{array}$ & $\begin{array}{l}0.27 \\
0.25\end{array}$ & $\begin{array}{l}0.29 \\
0.27\end{array}$ & $\begin{array}{l}0.26 \\
0.25\end{array}$ & $\begin{array}{l}0.27 \\
0.25\end{array}$ & $\begin{array}{l}0.27 \\
0.25\end{array}$ & $\begin{array}{l}0.31 \\
0.29\end{array}$ \\
\hline $\begin{array}{c}\text { August } \\
1-15 \\
16-31\end{array}$ & $\begin{array}{l}0.25 \\
0.23\end{array}$ & $\begin{array}{l}0.28 \\
0.25\end{array}$ & $\begin{array}{l}0.24 \\
0.22\end{array}$ & $\begin{array}{l}0.26 \\
0.24\end{array}$ & $\begin{array}{l}0.24 \\
0.21\end{array}$ & $\begin{array}{l}0.24 \\
0.21\end{array}$ & $\begin{array}{l}0.25 \\
0.22\end{array}$ & $\begin{array}{l}0.29 \\
0.28\end{array}$ \\
\hline $\begin{array}{c}\text { November } \\
1-15 \\
16-30\end{array}$ & $\begin{array}{l}0.08 \\
0.06\end{array}$ & $\begin{array}{l}0.10 \\
0.07\end{array}$ & $\begin{array}{l}0.07 \\
0.04\end{array}$ & $\begin{array}{l}0.09 \\
0.06\end{array}$ & $\begin{array}{l}0.07 \\
0.05\end{array}$ & $\begin{array}{l}0.07 \\
0.05\end{array}$ & $\begin{array}{l}0.05 \\
0.03\end{array}$ & $\begin{array}{l}0.12 \\
0.10\end{array}$ \\
\hline $\begin{array}{c}\text { December } \\
1-15 \\
16-31\end{array}$ & $\begin{array}{l}0.05 \\
0.03\end{array}$ & $\begin{array}{l}0.05 \\
0.03\end{array}$ & $\begin{array}{l}0.03 \\
0.02\end{array}$ & $\begin{array}{l}0.05 \\
0.04\end{array}$ & $\begin{array}{l}0.03 \\
0.04\end{array}$ & $\begin{array}{l}0.04 \\
0.03\end{array}$ & $\begin{array}{l}0.02 \\
0.02\end{array}$ & $\begin{array}{l}0.07 \\
0.07\end{array}$ \\
\hline
\end{tabular}


The amount of applied water (D) should be equal to the ET between irrigations, adjusted for the system's irrigation efficiency (IE):

$$
\mathrm{D}=\mathrm{ET} \div \mathrm{IE}
$$

An IE value of 0.70 to 0.75 is recommended for wheel-line sprinkle irrigation systems; for centerpivot sprinkle systems, use an IE value of 0.85 . There are problems with using this equation for flood-irrigated fields, and we discuss those later.

\section{Sprinkle irrigation}

A sprinkle irrigation system, particularly a centerpivot sprinkle system, can apply a small amount of irrigation water with a relatively high degree of uniformity, in contrast to a flood-irrigation system. Use equation 2 to estimate how much irrigation water to apply. Bear in mind that it is difficult and can even be impractical to apply a small amount of water using a wheel-line or hand-move sprinkle system because the short irrigation set times would require such frequent moves of equipment. Center-pivot systems are better suited to small applications of water.

Little surface runoff generally occurs under sprinkle irrigation. The primary loss of water is to deep percolation, and you can reduce deep percolation by decreasing the irrigation set time.

\section{Flood or border irrigation}

A number of factors make the application of small amounts of water difficult when you use flood irrigation. First, the water's infiltration rate into the soil determines how long an irrigation set will have to be in order to infiltrate a desired amount of water into the field. Infiltration rate also determines to a large extent the rate at which water flows across the field. Because this infiltration rate is very difficult to measure, growers rarely understand it in any quantitative way. Instead, they use observation and a trialand-error approach to estimate how long an irrigation set has to be. Second, it takes a certain flow rate and amount of applied water simply to get the water to the far end of the field. This initial amount may exceed the small soil amounts of moisture depletion that might occur under frequent flood irrigations. Third, it is the nature of flood irrigation that it has to generate surface runoff in order to ensure that sufficient irrigation water has time to infiltrate the lower part of the field. Because of this surface runoff (and because the amount of surface runoff is usually unknown), the total amount of applied water would have to be greater than is indicated in equation 1 .

Surface runoff is the primary form of water loss under flood irrigation of finer-textured soils. Flood irrigation also involves a large amount of ponding on the soil surface as the water flows down the field. Once the irrigation water is cut off, this ponded water continues to flow down the field. Some of it infiltrates the soil, particularly along the lower part of the field, and some becomes surface runoff.

Field studies have shown that by cutting off the irrigation water when the flowing water has reached about 80 to 90 percent of the way across the field, you can substantially reduce the amount of surface runoff. Data from a field demonstrating this appear in Table 3. In this case, water reached the end of the field after about 625 minutes of irrigation. The grower's normal practice of cutting off the irrigation after 800 minutes resulted in 2.8 inches of runoff, and the infiltration time of 7.1 hours at the end of the field far exceeded the amount of time needed to infiltrate the desired depth of water at the end of the field (2.6 hours). Cutting off the irrigation water after 600 minutes of irrigation reduced the runoff to 0.5 inches while still allowing sufficient infiltration time (2.7 hours) at the end of the field. The irrigation water failed to reach the end of the field when the grower used a cutoff time of 500 minutes. 
Table 3. Effects of cutoff time (the length of an irrigation application) on the total amount of water applied, the infiltration time at the far end of the field, and the amount of surface runoff

\begin{tabular}{cccc}
\hline Cutoff time* $^{*}$ & Applied water & Infiltration time & Surface runoff $^{\dagger}$ \\
\hline minutes & inches & hours & inches \\
800 & 12.8 & 7.1 & 2.8 \\
700 & 12.1 & 5.0 & 1.6 \\
600 & 11.2 & 2.7 & 0.5 \\
500 & 9.8 & 0 & 0 \\
\hline
\end{tabular}

* Time from the start of irrigation to cutoff.

${ }^{+}$Time available for water to infiltrate the soil. The amount of time needed to infiltrate the desired amount of water into the soil was estimated to be 2.6 hours.

Recovery and reuse of any surface runoff should also be considered, particularly under drought conditions. You can use a tailwater ditch and pond at the end of the field to collect the runoff and then pump the collected water back to the head of the field. Pumped surface runoff should be used to irrigated border checks that were not irrigated by the main irrigation water supply during the irrigation set. Another approach is to collect the tailwater in a pond and then use it to irrigate another field.

\section{Summary}

To recap, water management strategies for coping with drought conditions include the following:

- Strategy 1: Reduce the irrigated acreage.

- Strategy 2: Start early in the crop season with full irrigation and continue it until the water supply is used up. Plan on following that with no irrigation.

- Strategy 3: Practice deficit irrigation over the entire crop season by applying smaller amounts of water than the crop would

require if you were trying for maximum yields between cuttings.

While the returns to land and management for strategies 1 and 2 show no particular economic advantage for either one, strategy 2 has the advantage that it reduces the possibility that further allocation reductions later in the crop season will affect the operation. (The economics of strategy 3 were not evaluated here because of a lack of cost data for fields under deficit irrigation.)

Making the most of a limited water supply requires that you make sure your irrigation is efficient during the period when you fully irrigate the alfalfa, as occurs under strategies 1 and 2. This involves reducing losses to deep percolation and surface runoff (a major area of loss under flood irrigation). You can reduce percolation losses from sprinkle irrigation if you decrease the irrigation set times. To reduce surface runoff losses from flood irrigation, cut off the water before it reaches the end of the field. 


\section{For More Information}

To order or obtain ANR publications and other products, visit the ANR Communication Services online catalog at http://anrcatalog. ucdavis.edu or phone 1-800-994-8849. You can also place orders by mail or FAX, or request a printed catalog of our products from

\section{University of California}

Agriculture and Natural Resources

Communication Services

1301 S. 46th Street

Building 478 - MC 3580

Richmond, CA 94804-4600

Telephone 1-800-994-8849

510-665-2195

FAX 510-665-3427

E-mail: anrcatalog@ucdavis.edu

(C2011 The Regents of the University of California Agriculture and Natural Resources

All rights reserved.

\section{Publication 8448}

ISBN-13: 978-1-60107-741-7

The University of California prohibits discrimination or harassment of any person on the basis of race, color, national origin, religion, sex, gender identity, pregnancy (including childbirth, and medical conditions related to pregnancy or childbirth), physical or mental disability, medical condition (cancer-related or genetic characteristics), ancestry, marital status, age, sexual orientation, citizenship, or service in the uniformed services (as defined by the Uniformed Services Employment and Reemployment Rights Act of 1994: service in the uniformed services includes membership, application for membership, performance of service, application for service, or obligation for service in the uniformed services) in any of its programs or activities.
University policy also prohibits reprisal or retaliation against any person in any of its programs or activities for making a complaint of discrimination or sexual harassment or for using or participating in the investigation or resolution process of any such complaint.

University policy is intended to be consistent with the provisions of applicable State and Federal laws.

Inquiries regarding the University's nondiscrimination policies may be directed to the Affirmative Action/Equal Opportunity Director, University of California, Agriculture and Natural Resources, 1111 Franklin Street, 6th Floor, Oakland, CA 94607, (510) 987-0096. For information about ordering this publication, telephone 1-800-994-8849. For assistance in downloading this publication, telephone 530-754-3927.

To simplify information, trade names of products have been used. No endorsement of named or illustrated products is intended, nor is criticism implied of similar products that are not mentioned or illustrated.

An electronic copy of this publication can be found at the ANR Communication Services catalog website, http://anrcatalog. ucdavis.edu.

\section{$\bigcup_{P \in R}$}

REVIEWED This publication has been anonymously peer reviewed for technical accuracy by University of California scientists and other qualified professionals. This review process was managed by ANR Associate Editor for Land, Air, and Water Sciences Anthony T. O'Geen.

web-6/11-WJC/RW 